\title{
A COMPARATIVE EVALUATION OF THE DELAWARE AND MARYLAND CLOSE CORPORATION STATUTES
}

\author{
EDWIN J. BRADLEY*
}

In 1967 both Delaware and Maryland enacted close corporation legislation. The two statutes differ significantly in their approach to the problems of the "incorporated partnership." In this article the author undertakes an evaluation of the policies represented in the two enactments and concludes that the Maryland effort yields the most insightful close corporation statute legislated to date.

A PPLICATION of traditional business corporation laws to the close corporation has produced two evils. Business associates have been deprived of the right to use arrangements, vital from a practical point of view, for allocating inanagement of the business; for determining profit sharing; and for structuring an effective decision-1naking process. Equally insidious has been the devastating effect on minority shareholders of judicial tolerance of the power conferred upon majority directors and shareholders by traditional corporation statutes. Because general corporation laws do not deal satisfactorily with the problems of the close corporation, several states have enacted special close corporation provisions. The inost recent examples of this trend are the 1967 enactments in Delaware and Maryland. The approach taken by these two states differs significantly, however. This article will undertake a comparative policy evaluation of these latest legislative efforts to rationalize the legal environment of the close corporation. ${ }^{1}$

\section{Legislative Policy for Close Corporations}

It will be the author's thesis that close corporation legislation should be animated by two fundamental principles. First, a very far-reaching contractual freedom should be extended to business associates to structure the

* A.B. 1950, Mount St. Mary's College; LL.B. 1955, Georgetown University Law Center. Professor of Law, Georgetown University Law Center.

${ }^{1}$ For an analysis of prior close corporation legislation see Bradley, Toward a More Perfect Close Corporation-The Need for More and Improved Legislation, 54 GEo. L.J. 1145 (1966); Folk, Corporation Statutes: 1959-1966, 1966 DuKE L.J. 875, 946-57; Folk, The Model Act and the South Carolina Corporation Law Revision, 18 BUS. LAWYER 351 (1963); Latty, The Close Corporation and the New North Carolina Business Corporation Act, 34 N.C.L. Rev. 432 (1956); O'Neal, Developments in the Regulation of the Close Corporation, 50 CORNELL L.Q. 641 (1965); Stevens, Close Corporations and the New York Business Corporation Law of 1961, 11 BuF- 
ultimate and day-to-day control of the business, to make arrangements for allocation of the earnings and for asset distribution, and to establish ground rules for the transfer of ownership interests and the dissolution of the corporation. Secondly, legislation governing close corporations should give full and explicit emphasis to other consequences of the contractual origin of the close corporation and the fiduciary relationship of the associates. While close corporation statutes must rescue that institution from the planning inhibitions impressed on it by blackletter-minded judges, the enactments must also liberate minority participants from the prospect of control and profit-sharing arrangements to which they did not freely assent. This goal can be accomplished partly, at least, by a legislative pattern marked by a consistent and express demand for unanimity where creation or change of the basic business arrangements is involved.

Complete effectuation of the reform, however, cannot be realized by a legislative policy which permits the parties an unlimited choice in the application of every provision intended for the close corporation. A definitional approach which merely serves to limit the class of conporations eligible for choice of close corporation status does not give the needed assurance that in all corporations which have the functional characteristics of the close corporations, ${ }^{2}$ the "freeze-out" or other oppression of the minority shareholders cannot occur. Thus, definition is properly employed to compel conformity to legislatively-weighed operational standards.

Close corporation statutes should be completely permissive with respect to how the business is to be run. Draftsmen must overcome the temptation to pronounce mandatory procedures which the proponents beheve are the "best" way to run a close corporation or to outlaw procedures which are felt to be "too flexible," for there is no "best" way to solve the planning problems in a close corporation. Each solution must be tailor-made. Unfortunately, draftsmen of close corporation statutes write against a background

FALO L. REV. 481 (1962); Comment, Statutory Recognition of the Close Corporation in Florida, 16 U. FlA. L. Rev. 569 (1964). See generally F. O'NEAL, 1 Close CoRPoratTons §§ 1.13-.14 (1958).

The Model Business Corporation Act remains in a retarded form as far as the close corporation is concerned. The Act authorizes high vote requirements for shareholders ( $\$ 136)$ and directors ( $\S 37)$, and informal action by shareholders ( $\$ 138$ ) and directors ( $\$ 39 \mathrm{~A}-$ Optional). Petitions for dissolution are allowed on an enlarged basis by $\S 90$. The most notable example of stunted growth is the continuing insistence on three directors even in a one or two-man situation. The only hope until the Model Act and its progeny are amended seems to be judicial enlightenment. See, e.g., Galler v. Galler, 32 Ill. 2d 16, 203 N.E.2d 577 (1964). But see Burnett v. Word, Inc., 412 S.W.2d 792 (Tex. Civ. App. 1967) for a reiteration of old errors.

2 The close corporation as it is found in the market place cannot be defined precisely, although corporations having very few stockholders all of whom are likely to be active in the operation of the business and whose shares are subject to transfer restrictions have been referred to as close corporations or incorporated partnerships. 
of judicial hostility which has occasionally led to a most convoluted and overly-detailed statutory approach. The enactment of only sweeping general principles precipitates the danger that courts will not enforce specific arrangements, and thus creates a lack of certainty which hampers effective planning. For this reason, olose corporation statutes should use straightforward, lucid declarations cataloging what may and inay not be done with respect to the important matters on which general corporation laws have proved too inhibiting.

\section{Summary of the Delaware and Maryland Statutes}

The Delaware statute. Delaware defines a close corporation as one which disavows a public offering of its securities, restricts in soine way the transfer of its shares, places a limit on the number of its shareholders not to exceed thirty ${ }^{3}$ (actually sixty),${ }^{4}$ and recites in its certificate of incorporation that it is a close corporation. The application of close corporation provisions is voluntary, however, for both new and existing corporations. 5 A section of the Delaware statute not contained in the Close Corporation Subchapter permits the utilization of only one or two directors in corporations which have, respectively, one or two shareholders. ${ }^{6}$ There is no close corporation provision specifically permitting so few directors where the number of shareholders exceeds one or two, although the broad license found in section 354 to adopt partnership-like arrangements relating to the management of the close corporation business perhaps authorizes the use of a single managing director irrespective of the number of shareholders. Shareholder voting agreements between two or more shareholders are legalized im section 218, another non-close corporation provision, but they are limited in time to ten years. Enforcement of voting agreements by the grant of specific perfornance is a matter for the courts and remains unsettled. ${ }^{7}$ Irrevocable proxies, which may provide an alternative to the enforcement uncertainty of shareholder agreements, are described in section 212 (c) as those which are both stated to be irrevocable and coupled with an interest sufficient in law to support an irrovocable power. The interest need not be in the stock itself but, in accordance with subsection $\mathbf{C}$, may be in the corporation generally.

${ }^{3}$ Dec. Code ANN. tit. 8, $\S \$ 342,343$ (Spec. General Corp. Law Pamphlet 1967).

' See id. \$342(a) (1), (c). Section 342(c) permits stock held jointly, in common, or by the eutireties, to be attributed to one stockholder.

"Id. § 344.

- Id. § 141(b).

'In Ringling Bros.-Barnum \& Bailey Combined Shows, Inc. v. Ringling, 29 Del. Ch. 610, 53 A.2d 441 (1947), the Delaware Supreine Court appears to have refused specific performance of the promise to vote stock in unison as the parties would decide or as determined by arbitration. The court merely nullified votes cast in contravention of the shareholder agreement. 
Three sections of the Close Corporation Subchapter deal with control and profit sharing matters crucial in the close corporation:

(a) Section 350 allows a majority of the shareholders to agree in a manner which restricts director discretion.

(b) Section 354 permits agreements "among stockholders" (whether this means any two, a majority, or unanimity is not stated) relating to any phase of corporation affairs, including inanagement of the business, dividends, employinent and arbitration. The fact that such agreements are tantamount to efforts to treat the corporation as a partnership is negatived as a ground for invalidation.

(c) Section 351 permits all of the shareholders to dispense with the board of directors and accept the management and control of the business by the stockholders directly. Under such an arrangement the stockholders are deemed to be directors. Shareholder direct control may be terminated, however, by vote of a majority of all of the shareholders, voting or not. Since this provision is unqualified, a higher vote requirement apparently may not be invoked for the purpose of terminating direct shareholder control.

While a two-thirds vote may voluntarily terminate close corporation status by effectuating an amendment of the charter eliminating any required provision, such as the limitation on the number of shareholders, ${ }^{8} \mathrm{a}$ higher vote may be stipulated. Involuntary termination by a transfer of stock to unqualified shareholders or a transfer which would cause the number of shareholders to exceed the statutory limit can be effectively prevented from disqualifying the corporation under section 347 by the operation of saving notice provisions and those permitting correction by the corporation. While provision is made for shareholder petitions to appoint a custodian on the occasion of board or shareholder deadlock, dissolution is a discretionary form of relief.9 Section 355 allows a provision in the certificate of incorporation for dissolution at the option of one shareholder or any specified number of shares. No buy-out option is conferred on other shareholders to stave off dissolution, nor is the court granted that discretionary flexibility. However, in the alternative, section 353 permits a court to appoint a "provisional director" on the petition of one-half of the board, one-third of the voting shares, or two-thirds of any other stock class, when the busimess of the corporation "can no longer be conducted to the advantage of the stockholders generally."

Transfers of securities may be restricted beyond common law tolerances. For example, consent restrictions are allowed. ${ }^{10}$ If a restriction is 1967).

${ }^{8}$ See Del. Code ANN. tit. 8, §§ 345(a), 346 (Spec. General Corp. Law Pamphlet

Id. $\S \S 226,352$.

${ }^{10} I d$. $\$ 202$ (c)(3). 
held to be invalid, section 349 gives the corporation a thirty day option to buy the shares at a fair price.

The Maryland statute. The outstanding policy feature of the Maryland statute is the consistent requirement of unanimity among all of the shareholders for action which initiates or changes arrangements of fundamental importance in the close corporation. A salient provision makes clear that whenever the statute specifies the assent of "all of the stockholders," no shares may be made non-voting by agreement of the parties.11 Maryland defines a close corporation as one which describes itself that way in a charter provision to which every shareholder has consented. ${ }^{12}$ Once attained, such status may be lost only by unanimous consent. ${ }^{13}$ Hence, in Maryland, close corporation legislation is inapplicable unless the parties freely choose the close corporation as a distinct form. And they may freely make that choice without having to demonstrate eligibility on the basis of either the number of stockholders of the corporation or the extent of trading in its stock.

In section 101 of its close corporation statute, Maryland adopts the partnership rule of delectus personarum, making a transfer of shares invalid unless it is consented to by all the stockholders or is consistent with an agreement entered into by every member of that group. The stockholder who is blocked from sale by an inability to obtain consent, albeit reasonably withheld, is entitled to require dissolution, absent an agreement to the contrary, as is the stockholder to whom an unsatisfied purchase commitinent has been made. ${ }^{14}$ New stock may not be issued unless all the stockholders consent; nor may the close corporation issue options, conventible securities, or voting debt securities. 15

All of the shareholders of the close corporation may agree upon a wide range of matters including management, stock transfer restrictions, voting, directorships, dividends or division of profits, employment, and dissolution. 16 The courts are exhorted to specifically enforce these agreements and are empowered to order dissolution where appropriate. Under section 105 , utilization of a board of directors may be dispensed with altogether by the associates, and management power may be directly exercised by them. However, the more familiar director approach may be preserved by taking advantage of the section 106 permission to have a single director where there is only one shareholder or, if there is more than one shareholder, where a single director suits the business plan and agreement. Dis-

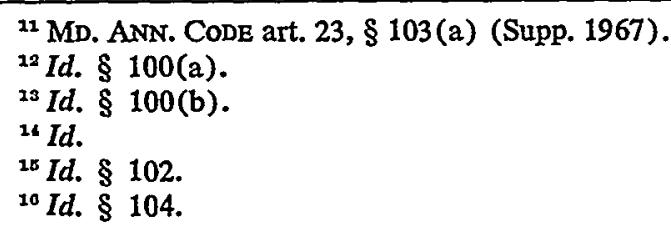


solution may be sought by any stockholder through judicial petition on the ground that internal dissension prevents conduct of the business to the advantage of all the stockholders. ${ }^{17}$ Increases in the number of shareholders will not spoil the close corporation status, for there is no numerical limitation in the definition.

\section{The Function of a Statutory Definition}

Unanimity as the sole definitive factor: Maryland. Maryland defines a close corporation as one which is identified as such in the charter. For new corporations this will require consent by all; for existing corporations, a unanimous vote of all of the stockholders, whether ordinarily entitled to vote or not, is required. 18 Removal of the charter statement conferring close corporation status may be accomplished only by charter amendment consented to by all the stockholders. ${ }^{19}$ One desirable consequence of this procedure is that status as a stockholder of a close corporation cannot be thrust upon a stockholder nor can that status be terminated rightfully except in the manner agreed upon by each stockholder. Since the mercantile equivalence of the partnership and close corporation have long been recognized, the legal equivalence of the basic contractual character of each relationship is properly recognized as well. On the other hand, when close corporation status may be freely chosen, as in Maryland, a person who participates in the routine incorporation of a business, or buys into a business with non-close corporation status, expecting to exercise a meaningful voice in managenent of the business, may well discover that change hes within the power of others. This power includes the means through which election under the new statute can be blocked, thereby leaving the business association under the traditional corporate law provisions with their failure of accommodation of the minority interest. It is noteworthy that a Maryland case, DeBoy v. Harris, ${ }^{20}$ held a charter amendment to be in violation of the parties' joint-venture "understanding" that no changes would be made in the capital proportions. The oral agreement was held to survive incorporation and to transcend, in legal effect, the provisions of the statute or charter amendment. Now that Maryland has a close corporation statute, does the failure to elect that status deprive the parties in existing close corporations of this and other protections against misuse of majority power? For example, now that the DeBoy v. Harris holding has been codified in section 102 of the Maryland statute, does that rule apply only to close corporations? Hopefully not. Sincé Maryland's close corporation regulatory provisions are applicable on a strictly voluntary basis, its courts must

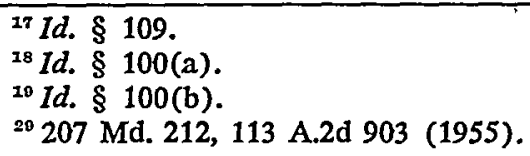


remain alert in order to protect the minority shareholder of non-electing close corporations.

Maryland allows high-shareholder and director quorum and voting provisions for the non-electing corporation. ${ }^{21}$ Three directors are invariably required. ${ }^{22}$ The articles may impose restraints on stock transfers but section 4(c) provides only that the restriction may not be "inconsistent with law," thus enabling the courts to nullify "unreasonable restraints." Since the statute says nothing of irrevocable proxies, common law principles will apply. This whole arrangement gives the courts the widest possible supervision of the non-close corporation and allows them to guard against misuse of inajority power in the non-electing close corporation as well. The ideal corporation statute, however, should go so far as to protect parties who become business associates under a routine, unplanned incorporation by functionally defining the close corporation to encompass all associations in which the potentiality for significant minority suppression exists. The legislative purpose would be to establish for the close corporation, statutorily defined, the principle of free choice of associates, and to outlaw less than unanimous shareholder agreements affecting control or impinging on director functioning or discretion. These things and more are done in Maryland for the electing corporation, but there is no effective regulation of the non-electing corporation. ${ }^{23}$

Corporations now in existence whose majority stockholders will resist the election because they enjoy the upperhand are unaffected by the Maryland statute. Similarly untouched are those formed in the future with too much optimism or without benefit of sound legal advice and planning for all the participants. The mandatory application of certain statutory provisions to all close corporations, as defined, will not prevent either unplanned situations nor will it force unwanted arrangements on all participants in these enterprises. Charter provisions prerequisite to election of that status generally and the use of the various statutory devices would remain for optional use but only by unanimous consent. Thus, it is felt that close corporation statutes may be made permissive enough to allow business associates to choose a highly conventional and traditional approaclı

${ }^{21}$ MD. ANN. CoDe art. 23, §§ 41, 42, 56 (1966).

${ }^{22} I d . \S 53$.

${ }^{23}$ In Honikman v. Ruedd, Inc., 363 F.2d 839 (5th Cir. 1966), a holder of $25 \%$ of the stock of a "Close Corporation" under the Florida statute, sought an order voiding a charter amendment which increased authorized capital. The stockholder urged the absence from the charter of a provision for amendment. The court routinely applied Florida general statutory charter amendment provisions to uphold the change. Unfair treatment of a minority shareholder should be inade innpossible by applying certain statutory provisions, such as the one in Maryland forbidding issuance of new stock without unanimous consent, to all close corporations as defined. 
to corporate life virtually along the lines of the hornbook corporate characteristics, but the burden should be on associates to plan for that kind of corporation on a unanimous, contractual basis.

Definitional factors in the Delaware statute. In defining the close corporation, the Delaware statute has departed from the trading or quotation test of other statutes ${ }^{24}$ but has substituted an equally elusive and uncertain element in the form of a ban on a "public offering."25 The pavlovian response of the corporate bar to that expression will be "twenty-five offerees." However, another definitional component in the statute tolerates sixty shareholders and, thus, at least that number of offerees. ${ }^{26}$ What is not clear is why the concept of investor protection should be allowed to intrude into this area at all. The purchaser of shares of stock oan be easily protected, and has been in this very statute, without resont to this definitional foray. It has yet to be demonstrated how investors are threatened by the wide availability of a business organization which admits of complete latitude in its government and otherwise sharply departs from the classic contours of the corporation, especially if unanimity is a pervasive requirement.

Definitions such as the one in Delaware, which represent a policy of containment of the close corporation, presumably result from a finding that the arrangements permitted "won't work" in a corporation that cannot fit the definition. Or is a finding made that in these non-qualifying corporations the parties "wouldn't want" thein? These decisions would seem properly left to the parties themselves. Since there is no exact, functional distinction between the close and non-close corporation, the statutory line between them should not be so abruptly drawn that the stockholders and managers of the corporation which fails to neet the definition are saddled with all the management stringencies of the conventional corporation statute.

In any case, the Delaware definitional elements do not in fact sharply curtail the use of close corporation control and management devices in non-qualifying corporations. Nor are they used to insist that all statutorilydefined close corporations comply with prescribed rules for the use of

${ }^{24}$ See, e.g., Fla. STAT. § 608.0100(2) (Supp. 1968); N.C. GEN. STAT. § 5573(b) (1965); N.Y. Bus. CoRp. LAW $\S 620$ (c) (McKinney Supp. 1967); S.C. CoDE ANN. \& 12-16.22(c) (Supp. 1965). A test based on whether the corporation's shares are regularly traded or quoted was reportedly believed to be too elusive for practical use and application. See E. Folk, The New Delaware Corporation Law (Corporation Service Company) 40-41 (1967).

${ }_{25}^{25}$ Del. Code ANn. tit. 8, § 342(3) (Spec. General Corp. Law Pamphlet 1967).

¿ See id. § 342(a)(1), (c); note 4 supra and accompanying text. 
arrangements which may be harmful to minority shareliolders. Eligible Delaware corporations which do not elect, and ineligible Delaware corporations, are given wide planning latitude since Delaware section 102(b)(1) may well insure to all corporations the contractual freedom conferred on the close corporation. That section states:

[T] he certificate of incorporation may also contain . . . (1) Any provision for the management of the business and for the conduct of the affairs of the corporation, and any provision creating, defining, limiting and regulating the powers of the corporation, the directors, and the stockholders, or any class of the stockholders, ... if such provisions are not contrary to the laws of this State. . . .

The Delaware act also specifically permits the following for the non-close corporation: one or two directors if there are as many shareholders [section 141(b)]; high director quorum and vote requirements [section 141(b)]; informal director action [section 141(f)]; broad delegation to committees [section 141(c)]; selection of the officers and agents by the shareholders [section 142(a), (b)]; stock transfer restrictions of the most stringent variety [section 202]; irrevocable proxies [section 212]; high shareholder quorum and voting requirements [section 216]; voting trusts and shareholder action [section 218]; informal shareholder action [section 228]; liberal dissolution of joint venture corporations [section 273]; petitions for dissolution upon deadlock [section 226]. Thus, a workable close corporation statute exists for all corporations regardless of the number of shareloolders, stock transfer restrictions, or public offerings, although it is true that in Delaware, as in New York, ${ }^{27}$ a legislative effort is made to confine the use of direct shareliolder inanagement to the statutorily defined close corporation. ${ }^{28}$ Delaware also limits the use of partnership-like agreements, arrangements restricting director discretion, and the shareholder dissolution option to the defined class of corporations. ${ }^{29}$ Nevertheless, because the manifold ineasures listed above are available to corporations which will not or cannot ineet the statutory definition of a close corporation, the careful planner will be able to serve his client's needs adequately. Consequently, the intricate Delaware provisions for guarding the close corporation's status seem hardly worth the effort.

Election in existing corporations of close corporation status. The close corporation form of business organization, often called an "incorporated partnership," should be largely equated to the partnership wherever feasible and should be subject to fundamental contract principles. This would mean that a stockholder must consent to the arrangements constituting the close corporation status-whether that classification was consciously under-

${ }^{27}$ See N.Y. Bus. CoRP. LAw § 620(c) (McKinney Supp. 1967).

${ }^{28}$ See Del. Code ANN. tit. 8, § 351 (Spec. General Corp. Law Pamphlet 1967).

${ }^{20}$ See id. \$ 341 . 
taken or imposed by law. Moreover, some stockholders of an existing corporation should not be given statutory sanction for imposing a new status on dissenting shareholders, at least not without appraisal rights. Yet, under Delaware section 344, the vote of the holders of two-thirds of the shares of stock of each class in an existing corporation seems to have been the intended basis to achieve close corporation status.

An impediment to achieving close corporation status without unanimous assent has been written into the Delaware statute, although apparently it was not intended. This "loophole" should protect the dissenting stockholder of an existing close corporation from unwanted and oppressive arrangements made possible through close corporation election by a twothirds vote. As a prerequisite to close corporations status, a Delaware charter must restrict the transfer of all of the issued stock in one or more of the ways permitted by section 202 . Section 202 (b) states that no restriction shall be binding "with respect to securities issued prior to the adoption of the restriction unless the holders of the securities ... voted in favor of the restriction." Thus, the objection of any shareholder to the election of close corporation status may make a purported election legally ineffective even though the two-thirds class vote requirement of section 344 is met.

If this "loophole," for some reason not evident, is not effective to block the election, what protection exists for the minority? Could the close corporation election be blocked in existing corporations having a shareholder unanimity requirement for charter amendments? Perhaps not. Section 341 states that unless a corporation elects to become a close corporation "in the manner prescribed in this subchapter," it shall be subject to the general provisions of the corporation statute. A court might find that section 344's provision for a two-thirds vote presents a bimding statutory norm for the procedure which must be followed to achieve close corporation status. Yet, there is no good reason, except wholly irrelevant ideas about the inefficiency of unanimity, to msist on the preeminence of the two-thirds majority provision over an existing unanimity agreement. In any case, if there is no high vote requirement in an existing corporation, the eleoting amendment is possible unless a shareholder is also a director and is able to block the required board resolution because of a high vote requirement under section 141(b).

Section 354 permits far reaching "partnership" type arrangements respecting management, dividends, employment, and arbitration "among the stockholders," by written agreeinent, bylaw, or certificate provision. What does "iamong the stockholders" mean? If two-thirds of the stockholders elect close corporation status, a majority may be able to agree to a host of provisions pursuant to section 354 , and presumably those charter provisions would be valid and enforceable. Curiously, the section 351 permis- 
sion for management by the shareholders imposes, as a condition precedent, consent of all holders of record, subscribers, incorporators and of all the outstanding stock, voting or not. Then, quite inconsistently and incomprehensibly, the section permits the certificate to be amended by majority vote eliminating this provision for shareholder management. Thus, by reserving in the majority the power to destroy a management structure to which it previously had acquiesced, the statute effectively insures ultimate control to that group, and transforms the unanimity requirement of section 351 into a trap for the unwary minority.

\section{Control Arrangements}

Shareholder voting agreements, voting trusts, irrevocable proxies: $A$ continuing conundrum in Delaware. Section 218(c) of the Delaware statute, one of the general corporation provisions, validates voting trusts or written agreements between two or more shareholders with respect to their voting rights, but only for ten years. The provisions of the typical voting trust statute on disclosure are necessary and desirable to protect public investors, and the typical ten year time limitation for the voting trust may be needed to avoid control abuse and to protect against managerial inefficiency. Hence, section 218 is needed for the non-close corporation to validate and regulate voting trusts and shareholder agreements, the latter being the functional equivalent of the voting trust when irrevocable proxies are attached. However, the section should not have been inade applicable to the close corporation, for it offends the basic principle that in the close corporation there should be an equal opportunity to participate in important matters affecting control and the distribution of earnings. Further, the section, if it must apply to the close corporation as it is inade to do, introduces a reactionary rigidity by imposing a ten-year limitation on shareholder voting agreements. Equating the voting trust and the irrevocable-proxy shareholder agreement is obviously cogent; but the correct compromise, accommodating the attributes of each, is to lift the time limitation from the voting trust-not to impose one on the shareholder voting agreement. ${ }^{30}$

There is an aspect of this matter which does create a real statutory drafting problem. The use of the voting trust or shareholder agreement can be oppressive to a minority shareholder even if a ten-year limitation is imposed. Under the approach of all olose corporation statutes to date, the application of the statute to the close corporation is not automatic; the parties must choose that status. But only by defining the close corpo-

${ }^{30}$ The New York scheme presents a desirable alternative, for under that state's statute no himitation is imposed on the close corporation shareholder agreement, N.Y. Bus. CoRP. LAW $\S 620$ (a) (McKinney 1963), and use of an irrevocable proxy is authorized, id. § 609(f). 
ration precisely, and by making certam close corporation provisions applicable to it, is it possible, for example, to eliminate the oppressive use of the voting trust or shareholder agreement in such corporations. A unanimity requirement for both will serve that end in such a statutory pattern.

Perhaps the most astonishing thing about section 218 of the Delaware statute is its perpetuation of the uncertainty over what is a voting trust as compared to a shareholder voting agreement which utilizes irrevocable proxies. The Ringling ${ }^{31}$ and Abercrombie ${ }^{32}$ cases created this frustrating conundrum, ${ }^{33}$ and the distinction is still necessary because certain steps must be taken to create a voting trust-transfer of the shares to the trustee and filing the voting trust agrcement at the corporation's principal place of busimess-which are unnecessary for the formation of a shareholder voting agreement. ${ }^{34}$ Delaware cases insist on compliance with the statutory preconditions whenever the substance of an arrangement makes it a voting trust. Since no policy compels a distinction between the two, it would have been preferable to abolish the statutory differentiation. If non-participating shareholders have a legitimate need to know of the creation of the voting trust, it would appear that they should be made aware of the formation of a voting pool. The mvestor should also know that the shares lie buys are subject to a voting agreement just as the statute assures that he will be informed of the voting trust when a voting trust certificate is tendered to him. The Delaware statute, however, does not take this approach; the voting trust remains subject to the stock transfer and filing requirements while the voting agreement remains free of these conditions. 35

Shareholder agreements and voting trusts in Maryland. Section 45 of the Maryland corporation statute, which is a non-close corporation provision, allows one or more shareholders to form a voting trust for a period not to exceed ten years, but any other shareholder may become a party to it and participate in the "privileges of such agreement," whatever that may mean. Presumably, this open-endedness would nullify any attempt by less than all of the shareholders to use a voting trust as an oppressive mechanism. Close corporation shareholder voting agreements are provided for in section 104(a) (4) and require the actual assent of all shareholders. Specific enforcement and dissolution provisions of section 104(d)

${ }^{31}$ Ringling v. Ringling Bros.-Barnum \& Bailey Combined Shows, Inc., 29 Del. Ch. 318, 49 A.2d 603 (1946), modified, 29 Del. Ch. 610, 53 A.2d 441 (1947).

${ }^{32}$ Abercrombie v. Davies, 35 Del. Ch. 599, 123 A.2d 893 (1956), rev'd in part, 130 A.2d 338 (1957).

${ }^{33}$ See Bradley, Toward a More Perfect Close Corporation-The Need for More and Improved Legislation, 54 GEo. L.J. 1145, 1167-75 (1966).

${ }^{34}$ Compare DeL. Code ANN. tit. 8, § 218(a) (Spec. General Corp. Law Pamphlet 1967), with id. § 218(c).

${ }^{35}$ See id. § 218(a), (c). 
make resort to a voting trust unnecessary to overcome the common law enforcement uncertainty concerning shareholder agreements. Moreover, no time limitation is placed upon a shareholder voting agreement in the Maryland statute.

Irrevocable proxies. While the Maryland statute is silent with respect to irrevocable proxies, such an arrangement may not be needed as a close corporation planning device when other workable options are available as under the Maryland provisions. For example, where all of the shareholders assent, section 104 of the Maryland statute authorizes, and provides for enforcement of, shareholder voting agreements which have no time limitation. The Delaware irrevocable proxy section is almost superfluous, on the other hand, simce it does no more than echo the hornbook principle. ${ }^{36}$ Yet, it will probably be possible to plan around the irrevocable proxy uncertainty in Delaware. Although rehance on shareholder voting agreements will not be fully satisfactory because of the ten-year time limitation, the planner may be served adequately by a section 350 agreement restricting director discretion, or a section 351 shareholder agreement relating to management, or a section 354 "partnership" type agreement regulating "the election of directors or officers or the employment of stockholders." Enforcement is another matter, however, simce a leading Delaware case refused specific performance of a shareholders' voting agreement. ${ }^{37}$

Classes of stock. Both the Delaware and Maryland statutes enable the parties to create classes of stock by appropriate charter clauses and to endow each class with enumerated rights, powers, preferences or designations. ${ }^{38}$ The Maryland statute specifically refers to voting powers and voting rights of each class. ${ }^{39}$ Delaware's section 151(a) speaks of "voting powers, full or limited, or no voting powers." There is mild uncertainty about just how far these provisions permit the parties to go. The New York statute is clearer in stating that the certificate may provide for the election of one or more directors by the holders of the shares of any class or series of stock, or the holders of bonds. 40

Agreements restricting director discretion. Section 350 of the Delaware statute expressly allows a majority of the stockholders to make agreements which restrict director discretion. Agreements parceling out the corporate offices, allocating its profits through salaries and bonuses, shap-

${ }^{30} \mathrm{Id}$. $\$ 212(\mathrm{c})$.

${ }^{37}$ Ringling v. Ringling Bros.-Barnum \& Bailey Combined Shows, Inc., 29 Del. Ch. 318, 49 A.2d 603 (1946), modified, 29 Del. Ch. 610, 53 A.2d 441 (1947). ${ }^{38}$ See Del. Code ANn. tit. 8, §§ 102(a)(4), 151(f) (Spec. General Corp. Law Pamphlet 1967); MD. ANN. CoDE art. 23, \$\$ 4(b)(5), (b)(6), (c)(1); 18 (a)(1) (Supp. 1967).

${ }^{30}$ MD. ANN. CoDE art. 23 \$§ 4(b)(6), 18(a)(1) (Supp. 1967).

${ }^{\circ}$ N.Y. Bus. CORP. LAW $\$ 703$ (a) (McKinney 1963). 
ing its dividend policy, and otherwise determining the management and control of the business of the corporation are sanctioned, even though some of the stockholders are excluded from them. Yet, since the actual language provides only that the agreement is not invalid "as between the parties to the agreement," courts may be able to prevent the use of this section to freeze out minority shareholders by refusing to sustain the agreement in the face of a protest by a non-participant in the arrangement. The court's hand may be strengthened if it resorts to section 354 which makes clear that arrangements that are appropriate for a partnership may be entered into "by the stockholders." Since "by the stockholders" may be read as meaning all of the stockholders, partnership-like arrangements among less than all of the shareliolders could be nullified as outside of this section.

Management by the shareholders. Section 351 of the Delaware statute authorizes a certificate of incorporation provision conferring business management on the stockholders rather than the board of directors. This step may be taken only by charter amendinent consented to by all stockholders and subscribers. Yet, the shareliolder management provision may be deleted by a majority vote. After eliminating shareholder management, the majority may proceed under sections 350 and 354 to erect arrangements which constitute a classic "freeze-out." It is indeed surprising to discover in a close corporation statute a legislatively supplied blueprint for the entrapment-like exclusion of minority shareholders from the organie control arrangement of the corporate business. In light of the majority's unqualified statutory right to jettison management, no such arrangement would be advisable when planning for protection of the interests of the minority. Since the operational scheme to be utilized upon suspension of shareholder management must be agreed to in advance, this other agreement might as well be used from the beginning. Use of the shareholdermanagement privilege is also unnecessary from a practical viewpoint when there are two stockholders or factions, as in a fifty-fifty share-split situation, for two directors and two classes of stock, along with the agreements permitted under sections 350 and 354, will serve well enough as the control arrangement.

Section 105 of the Maryland statute seems to permit management by the shareholders only along lines traditionally associated with board of director functioning. While the power to manage the business and affairs of the corporation may be lodged in the sliareholders as a body, it must be exercised by them in a manner involving meetings, quorums, and voting majorities. Of course, special voting requirements may be agreed upon, but a fully open-ended statutory right to allocate ultimate managerial power seems to be lacking in the approach taken by section 105. Subsection (6) is important for it provides that action by stockholders "shall be 
taken by the voting of shares of stock as provided in this article." Prolix and ingeniously drawn charter provisions, together with other devices, might enable counsel to satisfy this requirement and still supply his clients with the allocation of managerial autonomy desired. Close incorporators, however, should be freed entirely from any statutory "norm" with respect to the distribution of managerial power. Suppose, for example, that business associates desire to confer absolute autonomy over one segment of the business upon a particular shareholder or agent while giving yet another shareholder or agent full power over a separate phase of the business. The Maryland statute does not establish clearly enough the legality of planning along these lines. Hopefully, section 104, which sustains stockholder agreements regulating "any aspect of the affairs" of the corporation including "management of the business" and the "exercise or division of voting power," will be used to validate arrangements of this kind. ${ }^{41}$

The Delaware statute may be sufficient on this point. The most confining provision in Delaware is subsection (2) of section 351, which states that the stockholders shall be deemed to be directors for purposes of applying the provisions of the corporation chapter. This may be read as requiring the shareholders to exercise their power as a body in a somewhat formal manner. Section 354 may rescue the shareholders from this situation, however, for it provides that written stockholder agreements or charter or by-law provisions relating to the management of the business shall not be invalid on the ground that the parties have sought to arrange their relations in a manner that would be appropriate among partners.

\section{Stock Transfer Restrictions}

Transfer of ownership interests in the close corporation. The Maryland statute's basic position on stock transfer by stockholders of the close corporation constitutes a marked reversal of philosophy from the traditional hornbook free-alienability premise. The new Maryland position, codified in section 101(a), is that shares of stock in a close corporation cannot be transferred without the consent of the other stockholders, unless otherwise agreed. This recognition of the functional equivalence of the close corporation and the partnership is, of course, an adoption of the partnership rule. 42 The shareholders of a Maryland close corporation may themselves agree on the consequences of a withheld consent, whether "reasonable" or otherwise, but the statute gives the stockholder who is denied consent the

${ }^{11}$ A preferable provision could have been borrowed from N.Y. Bus. CoRP. LAW $\S 620$ (b) (McKinney Supp. 1967). In pertinent part that section states: "A provision [shall be valid which] transfers to one or more shareholders or to one or more persons or corporations ... all or any part of [the] management [of the business of the corporation] otherwise within the authority of the board ...."

${ }^{3}$ See UNIFORM PARTNERSHIP ACT $\$ 31(1)(c)$; text preceding note 14 supra. 
right, absent a contrary agreement, to require dissolution. ${ }^{43}$ The same right, which appears to be automatic and non-discretionary, is extended to a stockholder who is party to an agreement on transfer restrictions if there is a default on a purchase obligation created by the agreement.

Suppose a majority shareholder wishes to transfer his interest. If there is no contractual deviation from the statutory provision which prohibits transfers without consent, the minority may withhold consent. If they do so, they cannot prevent dissolution by the majority holder. Thus, if the minority cannot finance their own purchase, forcing the majority to dissolve the entity may be their only way to stop a transfer to someone who is unacceptable as a business associate. Suppose, on the other hand, that a minority shareholder wishes to sell his interest. 44 The minority shareholder who is able to come up with a bona fide offer to purchase his shares and who is demed consent, absent other agreement, may pursue his statutory right to automatic dissolution unless one or more stockholders elect to purchase his shares pursuant to section 109(e).

The treatment of transfer restrictions in the Delaware statute seems incomplete. Section 202, which is applicable to all corporations, makes licit the imposition of restrictions on the transfer of securities such as those employing the first option, compulsory buy-sell or buy-out, consent, transferee-qualification, and subchapter S-motivated arrangements, as well as any other lawful restriction. Section 349 gives the corporation a thirtyday option to purchase the shares at their fair value if a restriction is held not to be authorized by section 202, which seems highly unlikely.

As noted, the Maryland statute introduces a way to deal with the situation where consent to transfer is sought and not obtained. The hard question of whether the refusal must be "reasonable" or "in good faith" is obviated by providing the would-be transferor with an automatic dissolution or buy-out remedy which is open to agreements enabling the shareholders to transfer on a more liberal basis or to waive the dissolution right. Thus, in Maryland stockholders may agree that consent may be withheld arbitrarily with no avenue of escape, as in a partnership, or they may construct whatever arrangement they see fit. The Delaware statute, however, seems less flexible. One able commentator has written that, presumably,

\footnotetext{
${ }^{3}$ See MD. ANN. CoDE art 23, § 101(b) (Supp. 1967).

"The practical difficulties associated with the sale of minority close corporation stock should be diminished by the careful statutory scheme which makes the classic freeze-out impossible in a Maryland close corporation. Since minority shares must be party to and have a powerful voice in changing the management and profit arrangements of a close corporation under the Maryland statute, purchase by an outsider becomes more feasible. Close corporation stock, under a statute safeguarding the rights of all stockholders as contracting parties, becomes a much more saleable commodity because of the assurance that every stockholder will be able to participate in working out the organic arrangements for management, control, and profit division.
} 
a statutory permission for the use of consent restrictions means that directors or shareholders must act reasonably in passing on the requested right to transfer. ${ }^{45}$ Does the Delaware statute mean what it says, that a "consent" restriction may be imposed, or will a "good faith" or "reasonable" qualification be read into the liberal grant of permission? No convincing reason exists why the parties should not be allowed to agree to give each other an absolute, arbitrary control over associates. In the absence of legislative clarity, the Delaware statute should be read by the courts as permitting close corporation stockholders to reject a proposed transferee without any possibility of judicial review of the purity of their motives. If the parties find this arrangement unpalatable, they should be permitted to plan accordingly. Lesser restrictions, including buy-sell agreements and dissolution power, are possible devices available to them. ${ }^{46}$

Imposing or eliminating transfer restrictions. The Maryland statutory scheme offers a clear guide to planning for transfer restrictions. Reliance may be placed on the statutory premise of no transfer without consent, which may be arbitrarily withheld, and on the statutory right to petition for dissolution which triggers a buy-out option. Alternatively, the parties may waive the dissolution option by so agreeing, ${ }^{47}$ giving each a completely free choice of associates. Or a "good-faith" or "reasonable" criteria for withholding consent may be agreed upon despite its uncertainties, possibly using arbitration to resolve any future conflict. In addition, an agreement with respect to dissolution may be dovetailed with this aspect of the close corporation agreement. Section 104(a)(2) of the Maryland statute makes it quite clear, however, that no transfer restrictions may be added or eliminated unless by consent of all of the shareholders. This is, of course, as it should be.

Similarly, under section 202(b) of the Delaware statute it is clearly impossible to impose a restraint on a stockholder without his consent. Removal of a transfer condition is another matter. If a restriction is contained in the certificate of incorporation, a majority may be able to effectuate the removal of the limitation under section 242 . The class vote requirement, however, might give a veto in a particular case. ${ }^{48}$ The Delaware courts seem to have repudiated the "vested right" approach in matters of this kind.49 Unless a high vote requirement has been agreed upon under sections 216 or 141 (b) or unless the Bechtold rationale is adopted, ${ }^{50}$ a bylaw-imposed restriction presumably is vulnerable to change by director

${ }^{15}$ See Folk, Corporation Statutes: 1959-1966, 1966 DUKE L.J. 875, 950.

${ }^{10}$ See Del. Code Ann. tit. 8, § 355 (Spec. General Corp. Law Pamphlet 1967).

${ }^{17}$ MD. ANN. Code art. 23, § 101(b) (Supp. 1967).

${ }^{48}$ See Del. Code Ann. tit. 8, § 242(d) (2) (Spec. General Corp. Law Pamphlet 1967).

${ }^{10}$ See Maddock v. Vorclone Corp., 17 Del. Ch. 39, 147 A. 255 (1929).

${ }^{\text {to }}$ See Bechtold v. Coleman Realty Co., 367 Pa. 208, 79 A.2d 661 (1951). 
or shareholder vote, depending on the bylaw provision relating to amendments. If the restriction is embodied in an agreement, hornbook contract principles should prevent unilateral change. The only provision of the close corporation subchapter which might have an impact on this problem. is section 354 which sustains certificate provisions, bylaws, or written agreements aimed at accomplishing partnership characteristics for the corporation. While the presence of section 202 may limit reliance on section 354 in planning for stock transfer restrictions, a court could be convinced that section 354 permits in the close corporation what is doubtful for corporations at large; namely, consent restrictions which give each stockholder an altogether untrammeled right to declare proposed transferees persona non grata. In addition, this section may affect the question of elimination of restrictions through bylaw or charter amendment. Unfortunately, the actual language offers little direct support, for there is no requirement of unamimity for the execution or amendment of these partnership-like arrangements.

\section{Dissolution}

Shareholder agreements. In Maryland, agreements on rightful dissolution by one or more stockholders, at will or upon the occurrence of a specified contingency, are included in the concise but comprehensive section 104 listing of matters upon which the parties are free to contract on a unamimous basis. That section and section 355 of the Delaware statute provide broad options on dissolution as a matter of right when not in contravention of the agreement of the parties. The Delaware requirement of unanimity for an amendınent to introduce a dissolution provision is quite sound and should have been followed consistently. However, the prerequisite is somewhat compromised by a provision in seotion 355(b) that a vote of two-thirds of all the outstanding stock will suffice if the certificate of incorporation contains a provision expressly allowing a dissolution amendment on those terms. Theoretically, each stockholder is aware of and fully comprehends charter provisions, but as a practioal matter this is not always true. If the intended purpose is to guard minority shareholders from unwanted dissolution provisions, it would seem preferable to dispense with the potentially harmful anticipatory consent provision and give each stockholder the protection of a veto exercisable when the question arises. The Maryland requirement of unanimity to change the close corporation compact, including every aspect of the business association, is the proper way to handle the matter.

A lingering doubt concerning the extent of contractual freedom on dissolution still extends to the question of whether the parties may agree to the power of "wrongful" dissolution. In the analogous partnership law, the unilateral termination power grew out of a judicial disinclination to 
coerce parties to remain in unpalatable personal relationships. Yet, some of the potential harshness of the right of dissolution has been tempered in the Uniform Partnership Act. While the Act preserves the principle that a partnership may be dissolved at any time by the express will of any partner irrespective of a contrary agreement between the partners, ${ }^{51}$ it is also provided that the remaining partners may elect to continue the business if they indemnify the dissolving partner against business-connected liabilities and pay the dissenter the value of his interest. ${ }^{52}$ Similar principles lave not yet been assimilated into corporation law; yet, the statutory separation of public-issue and close corporations may occasion the question of whether the partnership law of dissolution should be made available to participants in the close corporation. It would seem, lowever, that a power to dissolve the corporation in disregard of prior agreements by the parties is not needed if appropriate alternatives are presented in the governimg statutory sclieme. In addition to a sound provision for judicial dissolution, there should be an express recognition that close corporation associates are free to enter into any dissolution agreement which may comport with their planning objectives. The contractual freedom to state in detail when dissolution will be brought about and to use buy-out agreements with appropriate valuation and payment procedures will satisfy most needs.

Nonetheless, if the power were given to any stockholder to dissolve in contravention of the close corporation compact, the power could and certainly should be limited as it is in the analogous partnership situation. An agreement on a term of existence is intended to give associates a right to permanence of investment. This right requires that they have the option to sell the entire business and recover damages for a premature dissolution or to continue the business and pay the dissolving stockholder the book value of his interest less dannages. They should be permitted to petition the court not only to assess damages and fix the value of the corporation but also to order a fair payment period. This would make the exercise of the dissolution power most unattractive and of minimum pain to non-dissolving stockholders. It is believed that, on balance, the statutory power to dissolve in contravention of the agreement, hedged as suggested, ought to be established as a last-ditch escape for a close corporation associate who desires exit at any price.

\section{Dissolution By Judicial Decree}

Maryland: Electing close corporations. Maryland section 109(a) authorizes any shareholder to petition for dissolution on the ground that internal dissension prevents the conduct of the business to the advantage of the stockholders generally. Any stockholder or stockholders may elect to

\footnotetext{
${ }^{62}$ See UNIFORM PARTNERShIP ACT \& 31(1)(b), (2).

=2 Id. \& 38(2)(b).
} 
avoid dissolution by applying to purchase the petitioner's share at a price equal to their fair value as fixed by the court. If the section's evident spirit and intention are properly captured by the courts, judicial dissolution of the close corporation can be satisfactorily dealt with. However, the problems besetting dissolution by judicial decree of the close corporation could have been reduced even further by also including in the statute a more flexible judicial power with regard to remedies upon a showing of internal dissension. The English Companies Act provides an example which could have been copied. Specifically, section 210 of the act authorizes the court, when a winding-up would unfairly prejudice some members, to fashion any remedy which will end the complained of conduct. ${ }^{53}$

That the Maryland statute does not define "internal dissension" in the traditional terms of the failure to elect directors or the inability of the board of directors to act is significant. The unere fact that it is possible somehow for the business to be carried on at a profit does not mean that there exists the congenial and cooperative environment, marked by the mutual trust and confidence which should be characteristic of the incorporated partnership. The breakdown of that environment should mean that the business "can no longer be conducted to the advantage of the stockholders generally."54 The shift in emphasis in the Maryland statute from the benefits of a dissolution to all the stockholders to the advantages to be derived by all the stockholders from the continued conduct of the business should serve to distract the courts from the enterprise profitability test. In addition, it offers a means for ending the judicial reluctance to disband a profitable but dissension-plagued close corporation. The analogy to partnership principles becomes quite serviceable in the construction of this judicial dissolution provision. Particularly relevant would be English precedents which have accepted the logical consequences of viewing the close corporation as an incorporated partnership. Interpreting the section of the Companies Act which allows a judicial termination when such would be "just and equitable,"55 the court in In re Yenidje Tobacco Company, Limited, ${ }^{56}$ the leading English case giving expression to the partnership analogy, felt "bound to say that circumstances which would justify the winding up of a partnership ... are circumstances which should induce the Court to exercise its jurisdiction under the just and equitable clause and to wind up the company." With support from a treatise on partnership law, the court further stated that sufficient cause existed for dissolution of

\footnotetext{
${ }^{53}$ Companies Act of $1948,11 \& 12$ Geo. 6, c. 38, $\$ 210$.

${ }^{5}$ MD. ANN. Code art. 23, \& 109 (a) (Supp. 1967).

${ }^{55}$ Companies Act of 1948, 11 \& 12 Geo. 6, c. 38, § 222(f).

${ }^{50}$ [1916] 2 Ch. 426, 432 (C.A.).
} 
a close corporation which endured "such a state of animosity as precludes all reasonable hope of reconciliation and friendly cooperation. . . ."57

A question naturally arises over the importance to be given a judicial dissolution provision in a statute which also has a very liberal provision on dissolution by agreement of the parties. What weight should the court give to the fact that the parties have not made use of the privilege to agree to dissolution at the will of any shareholder or on the happening of specified events? If easy dissolution has not been agreed to, the court should first try to ascertain whether the certificate faithfully represents the business understanding of the parties. Routine incorporation will be with us forever and almost always fails to represent particular "imtent" on difficult questions. The better stance for a court faced with a routine incorporation would be to assume that the associates in a close corporation intended that partnership rules should apply. Thus, they should not be understood as having agreed to stay together without exception. Next the court should ascertain whether the actual intent of the parties is expressed in a "gentlemen's agreement"58 or a prior partnership agreement which the parties understand to govern their incorporated existence. It would be regrettable if the courts were to take the view that a failure to resort to a liberal dissolution provision creates a bias against the grant of judicial dissolution, for the planning alternative which would be forced upon associates would be the universal use of the dissolution at will agreement. Moreover, such a view would take away a highly desirable planning option-that of rejecting too-easy dissolution in favor of arbitration or some other form of dispute settlement.

Maryland: The election to purchase to avoid dissolution. Under the Maryland formulation, the election to purchase in section 109 (c) is intended as a method of avoiding dissolution. Does this mean that the election is operative only when the court finds that dissolution is appropriate because the business can no longer be conducted to the advantage of the stockholders generally? Or does it mean that the petitioning shareholder's stock may bo purchased by election prior to and regardless of the court's final decision? To some extent, the statute suggests the latter. Section 109 (c) states, for example, that if the parties cannot agree on a fair price, the court shall "stay the proceeding" and determine the fair value. This seems to contemplate an interruption of the dissolution proceeding. But it is also possible to understand this provision to mean that the election and valuation procedure are the second stage of the dissolution proceeding and come after a decision by the court of equity that the statutory circumstances for dissolution exist. One point seems clear: if the

${ }^{67}$ Id. at 430, citing N. LindLey, PArtnership (1860).

${ }^{68}$ See DeBoy v. Harris, 207 Md. 212, 113 A.2d 903 (1955); note 19 supra and text following. 
election may only be made upon the filing of the dissolution petition, the statute would have to be regarded as having gone off on a rather odd tack, providing a means of avoiding any hearing at all on the question of dissolution. Surely the non-petitioning stockholders may resist the dissolution petition on the merits and, if they are unsuccessful, elect a purchase "to avoid dissolution." Delay oannot benefit purchasers, for section 109(c) designates the filing date for the petition as the date at which the fair value is to be fixed and from which interest is to be calculated. In fact, however, this statutory structure tends to deny the non-petitioning shareholders their day in court on the dissolution issue.

The Maryland statute should be read as allowing an immediate election to purchase by the non-petitioning shareholders. If they are willing to buy out the petitioner, no finding of the existence of the statutory requirement for judicial dissolution is necessary. Common sense dictates that if the petitioner has sought a remedy of dissolution, which is statutorily conditioned by the right of purchase in other stockholders, the purchase should not be made subject to a finding that the petitioner is entitled to dissolution, unless that question is put in issue by the purchasers. Further, the right of the non-petitioning stockholders to purchase prior to settlement of the dissolution question does not involve an inimical limitation on the court's discretion to find in favor of the purchasers on the dissolution question, for their desire to disassociate themselves with the corporation can be fulfilled.

The election to purchase may relieve the minds of those courts who have shown themselves to be troubled by the blackmail aspects of a dissolution petition. ${ }^{59}$ If a petitioner had been more sinned against than sinning, a court in the past may have nevertheless refused dissolution because it suspected that the plaintiff was trying to bludgeon the defendant into a buy-out at an inflated price. A buy-out election at a fair price and on an installment payment schedule, both fixed by the court, will be a satisfactory answer in many cases. Where the petitioning stockholder is also guilty of causing the deadlock or dissension, and the other shareholders are financially unable to buy, the purchase election gives them no alternative but to fight the dissolution. The remedy remains discretionary, however, and they may persuade the court to withhold dissolution.

Another aspect of this problem arose in a recent Connecticut case. In Sussman v. Riverbank Motors Corporation ${ }^{60}$ a holder of fifty percent of the stock of a corporation filed a dissolution petition alleging an inability to break a deadlock caused by the equal division of the stock. When the

\footnotetext{
${ }^{60}$ See, e.g., In re Radom \& Neidorff, Inc., 307 N.Y. 1, 119 N.E.2d 563 (1954); Jackson v. Nicolai-Neppach Co., 219 Ore. 560, 348 P.2d 9 (1959). See generally Chayes, Madame Wagner and the Close Corporation, 73 HARv. L. REv. 1532 (1960). ${ }^{\circ 0} 154$ Conn. 289, 224 A.2d 716 (1966).
} 
other fifty percent stockholder applied to the court to have the fair value of the petitioner's shares appraised in order to exercise his statutory option of purchasing the petitioner's shares, ${ }^{61}$ the petitioner withdrew his petition forthwith. Since the appraisal and purchase election were found to be ancillary to the dissolution petition, the withdrawal of that petition was held to require dismissal of the appraisal application. The court believed that appraisal and purchase were meant by the legislature as a means of allowing the corporation to be continued and that the withdrawal of the petition for dissolution accomplished the same result. ${ }^{62}$ It is possible to disagree with the court's reading of the legislative intent as requiring an absolute cut-off of the purchase election. The legislature does not seem to have been concerned so much with preserving at all cost the corporate existence as with introducing flexibility into what has been a rigid, dissolution-or-nothing, judicial proceeding. If the worry is that dissolution is too drastic and that the threat of it is coercive, the ruling in this case may be seen as adopting too technical an approach. The statutory purchase application may well have assumed that the petitioner will be satisfied with a buy-out at a fair price, since he has evidenced his lack of interest in internal resolution of the corporation's difficulties.

Perhaps the statute should be treated as allowing the shareholder who has not originally asked for dissolution to make out his own case for the appropriateness of purchase as an alternative nethod of ending the dissension-racked situation. The stockholder who has not initiated the dissolution petition may choose not to resist the allegations of dissension and may concur in the need for some resolution of the deadlocked situation. The court might appropriately retain jurisdiction in the matter upon withdrawal by the original petitioners and allow the applicant for appraisal to demonstrate the appropriateness of that relief.

Maryland: Non-electing close corporations. The reports are replete with cases of judicial hesitance to grant dissolution. Statutory efforts to state criteria for the guidance of the court have mirrored these deep-seated inhibitions and may not result in a more liberal grant of dissolution. For example, the New York statute, as amended, probably does not overrule the leading New York case, In re Radom and Neidorff, Incorporated, ${ }^{63}$ which stressed the continuing profitability of the corporation there involved as a major reason for denying dissolution. The court also manifested reluctance to have its dissolution-granting discretion exercised in a way which would benefit one of the stockholders in his campaign to force the other to sell out at an unfair price. A court's difficulty is compounded when the facts suggest that dissolution of the corporation in question will

\footnotetext{
ar See ConN. Gen. Stat. ANN. § 33-384(a), (b), (d), (e) (1960).

02154 Conn. at 224 A.2d at 718.

${ }^{03}$ Me. Rev. Stat. ANN. tit. 13, § 542 (1964).
} 
be followed by the establishment of a new business by one or some of the stockholders, to the exclusion of the others, with what amounts to an appropriation of the good will of the existing corporation. In that situation, freezing the parties in the existing corporation is the only way that a court can prevent an inequitable result or a forced sale by the weaker stockholder. This points up the need for much more flexible remedies for deadlock or oppression in the close corporation such as court ordered buy-outs.

Section 79A(a) of the new Maryland statute allows the holder of not less than twenty-five percent of all the voting shares of any corporation to petition for dissolution whenever the shareholders are so divided that they cannot elect directors or the board is so divided respecting management that board action is impossible. But section 79A(b) permits any shareholder to petition for dissolution if the shareholders are so divided that they have failed for at least two consecutive annual meeting dates to elect directors. The court's "sound judicial discretion" is specified as the only criterion for granting dissolution under these circumstances. The question is thus raised whether this provision should be read literally so that deadlock-produced non-functioning alone should be sufficient to move the court to exercise its discretion. Since the Maryland statute does not restrict the court by imposing a test based on the benefits of dissolution, the way is open to the Maryland courts to declare the presence of the jurisdictional facts of shareholder or board deadlock sufficient to justify the grant of dissolution, as the Maine courts have already done. ${ }^{64}$ "If equity so requires," the test under the Maine statute, ${ }^{65}$ may well become the criterion for judicial dissolution in Maryland.

Section 79A of the Maryland statute also permits a petition for dissolution to be brought by any shareholder on the ground that "the acts of the directors or those in control of the corporation are illegal, oppressive or fraudulent." ${ }^{\prime \prime 6}$ In the non-electing close corporation, arrangements among less than all of the shareholders may produce intolerable management and profit sharing conditions for the minority shareholders. Thus, this section is vital as an aid to a minority relegated to a non-participating and non-profit sharing position, since it permits majority power to be effectively policed. Hopefully, the Maryland courts will agree with the Illinois case, Gidwitz v. Lanzit Corrugated Box Company, 67 which held that the exclusion froin a meaningful voice in the control and management of the enterprise is oppressive under the Illinois statute, a result which is consistent with the principle of equal voice in management recognized in the

\footnotetext{
${ }^{64}$ MD. ANN. CoDE art. 23, § 79A(b)(2) (Supp. 1967).

${ }^{\circ 5} 307$ N.Y. 1, 119 N.E.2d 563 (1954).

${ }^{80}$ See Laskey v. L. \& L. Manchester Drive-In, Inc., 216 A.2d 310 (Me. 1966).

${ }^{67} 20$ Ill. 2d 208, 170 N.E.2d 131 (1960).
} 
Uniform Partnership Act ${ }^{68}$ and which should be incorporated into close corporation analysis.

Delaware: Judicial dissolution. Earlier in this article inany close corporation devices were shown to be available for use in the non-electing Delaware close corporation. ${ }^{69}$ The use of shareholder or director unanimity agreements sharply increases the risk of deadlock and business paralysis. This is one reason why the Delaware statute inust address itself to the problem of dissolution on deadlock in non-electing close corporations. More importantly, however, the Delaware statute expressly sanctions several devices-shareholder selection of officers and agents, shareholders voting agreements, voting trusts and irrevocable proxies-which may be exploited by less than all the shareholders in a way obnoxious to minority shareholders.

Under two sections of the Delaware statute the Court of Chancery may appoint a "custodian" for a corporation who, at the Court's direction, may liquidate the enterprise. Section 226 of the Delaware statute allows petitions for appointunent by any shareholder on the occasion of shareholder inability to elect directors. No further criteria for dissolving the entity in such a circumstance, such as imjury to the corporation or unprofitability of the corporation, are supplied to the courts. Does the statute codify Paulman v. Kritzer Radiant Coils, Incorporated, ${ }^{70}$ in which the court, apparently applying a "profitability" test, refused dissolution to two shareholders who together held fifty percent of the stock of the corporation but were shut out from management and profits? While the absence of a test invites the construction that, if the stockholders cannot choose a governing body, the corporation ought to be dissolved, the coolness of the courts to that step will probably produce reliance on a "profitability" test similar to that adopted in Paulman.

Section 226 does, however, provide for custodial and dissolution petitions if the business is threatened with irreparable injury because the directors are so divided that board action is impossible and the shareholders cannot end the division. It is far from clear why a test of irreparable harm was thought to be appropriately imtroduced here when none appears in the prior subsection on shareholder deadlock. It would appear to be a far more serious matter if the board is paralyzed than if the shareholders cannot elect successors to directors who, under the statute, remain in office until their successors are elected. This means, for example, that even though the board is rendered impotent either because of a high director vote requirement or an evenly split board membership, actual or threatened irreparable injury to the corporation must be demonstrated. A sense of

\footnotetext{
${ }^{08}$ UNIFORM PARTNERshIP ACT \& 18(e).

${ }^{00}$ See text preceding note 26 supra.

${ }^{70} 37$ Del. Ch. 348, 143 A.2d 272 (1958).
} 
proportion requires one to believe that the courts will not be too demanding in this regard.

Section 352 of the Delaware close corporation subcliapter authorizes a petition for the appointment of a custodian if the shareliolders are managing the business under section 351 and are divided loopelessly. An irreparable injury test is included in the section, but, as pointed out earlier, the majority can terminate shareholder management, making its use improbable-a fact that seems to make discussion of this provision unnecessary.

Two sections of the Delaware statute pertain to the appointment of a provisional director. Under section 353 the Court of Chancery is empowered to appoint a provisional director when the board of directors is so divided that the business of the corporation can no longer be conducted to the advantage of the stockholders generally. Subsection 352(b) provides for appointment of a provisional director as an alternative to the appointment of a custodian. The test to be met for the appointment of a provisional director under this section is whether, as judicially determined, "it would be in the best interest of the corporation."

This statutory pattern raises a number of perplexing questions. Since sections 226 and 352 provide for the appointment of a custodian upon the application of any shareholder when the board or the shareholders (if they are managing under section 351) are deadlocked, what is the function of section 353? That section allows half of the board or the holder of onethird of the stock entitled to elect directors (or the holder of two-thirds of any class of stock entitled to elect directors, if there is more than one class) to bring a petition for the appointment of a provisional director. Does this mean that "any shareholder" 1nay ask only for dissolution under the former two sections, with the appointment of a provisional director a matter for the court to volunteer if the test of "irreparable injury" is not met? Yet, surely the section must tolerate petitions by any stockholder for the appointment of a provisional director, a less drastic remedy than dissolution, upon the satisfaction of the alternative test that the best interests of the corporation would be served by something short of dissolution. If any stockholder may ask for the appointment of a provisional director when, in the face of shareholder or director deadlock, that would be "in the best interest of the corporation," 11 it adds hittle to the statute to permit half of the board or certain stockholders to petition for the appointment of a provisional director only when the board is at an impasse. The appointment of a provisional director as an alternative to a custodian armed with liquidation authority must have been intended to add flexibility of judicial relief in a proceeding where dissolution is sought. However, the result will very probably be to make dissolution an almost inaccessible remedy.

\footnotetext{
${ }^{71}$ Del. Code ANN. tit. 8, § 352(b) (Spec. General Corp. Law Pamphlet 1967).
} 
If irreparable injury to the corporation is present or threatened, the appointment of a provisional director may be easily found to be in the best interests of the corporation by courts antipathetic to dissolution. So even if the petitioning stockholder gets over the irreparable injury hurdle, which is no mean feat in itself, he is likely to find it very difficult to convince the court that it would not be better to try the provisional director alternative.

Delaware: "Discontinuance" of a "joint venture" corporation. Delaware corporation law now contains what nnay be the first recognition of a new creature-the "joint venture corporation." Section 273 of the Delaware statute allows either stockholder of a two-shareholder, fifty-fifty owned, "joimt venture" corporation to petition for "discontimuance" of the joint venture. The petitioning stockholder must submit a plan for discontinuance and distribution. Presumably, this plan could call for the sale of all the stock or assets to a third party or the sale of one shareholder's stock to the other. Unless both stockholders file either their concurrence in the submitted plan, or an alternative plan, with the court within three months, and satisfy the court that the distribution has been completed within twelve inonths, the court may order dissolution.

This section is a curiosity. The solicitude sliown for the shareholders of this species of the close corporation is in sharp contrast to the incomplete legislative treatment of dissolution of other close corporations. Yet the section raises inany questions. Why are these "joint venture" corporations excused from having to elect close corporation status under section 344 in order to have this liberal discontmuance or dissolution privilege? Under section 355, the "joint venturers" could agree on dissolution by either party as a inatter of right, on some procedure for the sale of all of the stock or assets to a third corporation, on the right to tender the shares to the other for compulsory purchase, or on a right in either to negotiate a sale of all of the stock on behalf of both. Innumerable other exotic mechanisms could be employed to plan for the discontinuance of a "joint venture" corporation under the broad dissolution privilege of section 355 . Is a "joint venture comporation" one having a narrow business purpose and for a rather limited term? ${ }^{72}$ Is it a corporation formed by two corporations otherwise not associated and both of whom are occupied with separate substantial corporate activities? May the stockholders be two natural persons not otherwise associated professionally or in business, both elsewhere substantially involved in separate occupations? Because of these uncertainties, is it wise to provide that all two-shareholder, fifty-fifty owned corporations are "engaged in the prosecution of a joint venture" under the corporate form and hence are entitled to use this provision?

${ }^{72}$ But see Comment, The Joint Venture: Problem Child of Partnership, 38 CarIr. L. REv. 860 (1950). 
The joint-venture of the public-issue corporation world, involving two large corporations as the fifty-fifty stockholders, is unquestionably the intended beneficiary of this section. When sophisticated corporate managers cannot get along in a highly depersonalized joint venture deal, the statute provides them with an easy exit. Surely, the legislative intention is not a very niggardly exercise of discretion in granting discontinuance or dissolution by the Court of Chancery. The message is plain enough. These corporations want to be able to have partition or sale rather than endure a situation where the two stockholders are "unable to agree upon the desirability of discontinuing such joint venture and disposing of the assets."73 The section exemplifies the conviction of those who form and advise such corporations that, if the corporate partners are unable to get along harmoniously, divorce is the only sensible and civilized thing to do. This same sentinent, lrowever, shonld be applied to the close corporation whose shareholders number two or seven and whose ownership interests are split other than fifty-fifty.

Of course, it is true that the end of the affair for the joint venture corporation whose two shareholders are listed among the Fortune Magazine " 500 " can usually be readily handled in terms of dividing the property, by sale of assets or stock, or by a buy-out of one partner by the other. The feasibility of the petition for discontinuance in the case of lesser endowed corporations or persons is in direct ratio to the feasibility or likelihood of any plan for discontinuance by sale of stock or assets. Liquidation in the sense of an actual dismantling and auction sale is lighly unlikely to be the form of discontinuance of the corporations for whose special purposes section 273 was enacted. Yet, it may be the only alternative in the more prevalent close corporations to which the close corporation subchapter is directed.

\section{Other Close Corporation Problems}

The legal significance of the document containing the agreement. Delaware and Maryland require a charter of certificate provision to identify the close corporation. While Maryland's requirement is met by a mere cliarter statement that the corporation is close, 74 Delaware requires such a statement plus a limitation on the number of shareholders, restrictions on transfers, and a disavowal of "public" stock offerings. ${ }^{75}$ In Maryland, stockholder agreements involving management, stock transfer restrictions, dissolution, voting, employment, directorships, dividends, or division of profits may be embodied, pursuant to the authorization of section 104(a), in the cliarter, bylaws, or written instrument. A charter provision, how-

\footnotetext{
${ }^{73}$ Del. Code ANN. tit. 8, § 273 (a) (Spec. General Corp. Law Pamphlet 1967).

${ }^{74}$ MD. ANN. CoDE art. 23, § 100 (Supp. 1967).

${ }^{75}$ Del. Code ANN. tit 8, §§ 342, 343 (Spec. General Corp. Law Pamphlet 1967).
} 
ever, is needed to install management by direct stockholder action. ${ }^{76}$ Delaware similarly requires the certificate to house the agreement on stockholder management, ${ }^{77}$ and requires that the agreement be stated on each stock certificate, ${ }^{78}$ but then expressly permits the partnership-like agreement to be in the certificate, bylaws, or separate written agreement, ${ }^{79}$ and says nothing about where agreements which restrict the discretion of the board of directors must or may be found.

These disparities seem unnecessarily creative of legal tangles. The law should embrace the idea that the articles of close imcorporation, like articles of partnership, are the contract of the parties. Regulation of the privilege of limited liability and separate entity status require putting some matters on record. Yet, control, profit sharing, arbitration, and dissolution on stock transfer arrangements do not appear to require public filing, for the investor can be protected in other ways.

Financial provisions. Apart from the Maryland provisions banning new stock issues without unanimous shareholder consent ${ }^{80}$ and prohibiting voting semior securities, ${ }^{81}$ neither statute takes up the financial problems of the close corporation against the background of traditional rules on consideration for stock, dividend or share purchase regulations, excessive compensation, and other similar areas of corporate law. For example, the statutory prohibition against use of a promissory note or the promise of future services as valid consideration for stock is preserved in both statutes. $^{82}$ A persuasively supported recommendation for a change on this point has been ignored. ${ }^{83}$

Limited liability. As familiar corporate trappings are released by the use of the provisions of close corporation statutes, the danger remains that courts will be too prone to impose personal liability on the close corporation shareholders. Even now this is done in excess by resort to long-discredited "tests" for "piercing the corporate veil" too numerous and irrational to be worthy of comment here. Even the most harmless suggestions for close corporation reforms have been met by the not unreasonable objection that courts may use the parties' failure to behave in traditional cor-

${ }^{70}$ MD. ANN. CoDE art. 23, § 105(a) (Supp. 1967).

${ }^{77}$ DEL. Code ANN. tit. 8, § 351 (Spec. General Corp. Law Pamphlet 1967).

${ }^{78} \mathrm{Id}$.

${ }^{79}$ Id. $\S 354$.

${ }^{80}$ MD. ANN. CODE art. 23, § 102(a) (Supp. 1967).

${ }^{81}$ Id. $\S 102(\mathrm{~b})$.

${ }^{82}$ DeL. Code ANN. tit. 8, § 152 (Spec. General Corp. Law Pamphlet 1967); MD. ANN. CODE art. 23, § 22(a) (1966).

${ }^{83}$ Herwitz, Allocation of Stock Between Services and Capital in the Organization of a Close Corporation, 75 HARv. L. REv. 1098 (1962). 
porate fashion as a pretext for saddling associates with unlimited personal liability. ${ }^{84}$

While just and equitable limitations must be placed upon the limited liability mechanism, fundamental questions are begged by the literal enforcement of a "rule" that capital reasonably sufficient to meet anticipated obligations must be devoted to the business. Creditors, of course, are free to negotiate the terms upon which they will deal with the corporation. Thus, if a question exists as to the probable success of the venture, the creditors should insist upon an appropriate security for their advances or upon a personal guarantee of payment from shareholders. Because of this contractual freedom and the opportunity for prior investigation into the stability of an enterprise, creditors should not be entitled to a judicial inquiry into the "reasonableness" of the capitalization of the corporation. While creditors deserve protection against deception and unfair dealing, they are risk-takers in much the same sense as shareholders, for the creditors make their commitments in hopes that the operation will generate sufficient earnings to satisfy their claims. Consequently, except in cases where a sensible weighing of all the facts indicates a real abuse or perversion of the corporate privilege, courts ought to be constrained by statute from refusing to enforce limited liability principles. A statute might well provide:

The existence of the corporation as a legal entity distinct from its shareholders and the shareholders' privilege of limited liability shall not be affected by the fact that the affairs of the corporation are directly managed by the shareholders; nor by the fact that the board of directors of the corporation are parties to agreements respecting the exercise of their powers; nor by the fact that lawful restrictions are imposed upon the transfer of the stock of the corporation. In the absence of actual fraud, persons who voluntarily engage in any kind of dealings or transactions with a corporation, on a corporate basis, may look only to the assets of the corporation for the satisfaction of claims arising out of those dealings or transactions.

\section{CONCLUSION}

The decision of the draftsmen of the Maryland statute to attempt a fresh approach to the writing of a close corporation statute was a commendable one. The skill they brought to the execution of that decision is witnessed by the clarity and coherence of the series of provisions. Above all, the policy decisions, especially the insistence on unanimity, exemplified by this excellent legislation are sound and accomplish a large part of the appropriate objectives for legislation of this kind. In general, its directness, economy, and lucidity of style, as well as its substantive coherence, stamp the Maryland statute as the best close corporation statute to date. The legislation should have gone further, however, and compelled compliance

\footnotetext{
84 See, e.g., Garrett, John Doe Incorporates Himself, 19 BUS. LAWXER 535 (1964).
} 
to certain key provisions by all close corporations. This would have required a definition of the close corporation which specifies more than the voluntary election to be such a corporation. A definition tied to the number of shareholders would have served this purpose well..$^{85}$

Although the Delaware close corporation subchapter equips shareholders with a wide variety of useful planning arrangements, it lacks overall clarity because so many "close corporation" arrangements remain open to the non-electing corporation. Questionable policy choices were made by sanctioning less than unanimous agreements and alliances, not only with respect to non-electing corporations, but in electing or statutory close corporations as well. Further, while the statute adopts a definition of the close corporation, the definition is not used to enforce compliance with any provision but rather to limit use of the provisions which happen to be placed in the close corporation subchapter. Yet, this is not in fact terribly confining, for the use of close corporation devices in all corporations is liberally provided for elsewhere in the statute.

Hopefully, however, experience under these statutes will speed realization of the ultimate quest-a distimct and unchallengeable model close corporation statute.

${ }^{85}$ See Bradley, Toward a More Perfect Close Corporation-The Need For More and Improved Legislation, 54 GEo. L.J. 1145, 1189-91, 1196 (1966). 